\title{
APLIKASI METODE CERDAS UNTUK OPTIMASI CONTROLLER PID MOTOR DC BERBASIS FIREFLY ALGORITHM
}

\author{
Muhammad Ruswandi Djalal ${ }^{1 *}$, Hidayatul Nurohmah ${ }^{2}$, Andi Imran ${ }^{3}$, \\ Muhammad Yusuf Yunus ${ }^{4}$ \\ ${ }^{1,4}$ Teknik Energi, Jurusan Teknik Mesin, Politeknik Negeri Ujung Pandang \\ ${ }^{2}$ Teknik Tenaga Listrik, Jurusan Teknik Elektro, Universitas Darul Ulum \\ ${ }^{3}$ Teknik Sistem Tenaga, Jurusan Teknik Elektro, Institut Teknologi Sepuluh Nopember \\ *Corresponding author, e-mail: wandi@ poliupg.ac.id
}

\begin{abstract}
Abstrak - Pengontrolan kecepatan motor dc merupakan hal yang sangat penting untuk menjaga stabilitas operasi motor. Salah satu metode pengontrolan yang sering digunakan adalah kontroler proportional integral derivative (PID). Agar dapat beroperasi dengan optimal, kontroler PID membutuhkan penalaan parameter yang tepat. Salah satu permasalahan dalam penggunaan kontroler PID adalah penentuan parameter PID yang tepat. Dalam penentuan parameter kontroler PID selama ini masih dilakukan secara konvensional, sehingga kinerja PID menjadi tidak optimal. Untuk itu pada penelitian ini akan diusulkan salah satu metode penalaan parameter PID dengan menggunakan metode cerdas berbasis Firefly Algorithm (FA), untuk mengoptimasi dan menentukan parameter yang tepat dari PID. FA adalah salah satu metode cerdas yang terinspirasi dari perilaku firefly yang bergerak dimalam hari dengan kebiasaan berkedip, yang kemudian diadaptasi dan diterapkan menjadi algoritma cerdas untuk menyelesaikan masalah optimasi. Dari hasil yang diperoleh metode Firefly dapat dengan baik menala parameter PID, sehingga overshoot yang dihasilkan tidak ada dan settling time sangat cepat. Sebagai pembanding, pada penelitian ini juga akan dibahas penggunaan metode cerdas berbasis Bee Colony dan Cuckoo Search.
\end{abstract}

\section{Kata Kunci : PID, Bee-Colony, Cuckoo, Firefly, Settling time}

\begin{abstract}
Controlling the speed of dc motor is very important to maintain the stability of motor operation. One of the most commonly used control methods is the proportional integral derivative (PID) controller. In order to operate optimally, PID controllers need the correct parameter tuning. One of the problems in using PID controllers is the determination of the proper PID parameters. In the determination of PID controller parameters is still done conventionally, so the performance of PID becomes not optimal. Therefore, in this research we will propose one of PID parameter tuning method by using intelligent method based on Firefly Algorithm (FA), to optimize and determine the proper parameters of PID. The FA is one of the smart methods inspired by firefly behavior that moves at night with flashing habits, which are then adapted and applied into intelligent algorithms to solve optimization problems. From the results obtained the Firefly method can well tune the PID parameters, so the resulting overshoot does not exist and settling time is very fast. As a comparison, in this study will also discuss the use of intelligent methods based on Bee Colony and Cuckoo Search.
\end{abstract}

Keywords: PID, Bee-Colony, Cuckoo, Firefly, Settling time

Copyright $@ 2017$ JNTE. All rights reserved

\section{PENDAHULUAN}

Penggunaan kontroler Proportional, Integral, Derivative (PID) sudah semakin banyak, karena struktur sederhana, stabilitas yang baik dan ketahanan yang kuat [1]. Untuk mengoptimalkan kinerja motor dc, dibutuhkan kontroler tambahan. Salah satu jenis kontroler yang sering digunakan pada motor dc adalah kontroler PID. Penggunaan PID sebagai kontroler motor dc membutuhkan parameter yang tepat untuk kinerja yang optimal. Penentuan parameter PID selama ini masih berbasis konvensional, sehingga kinerja motor menjadi tidak optimal [2]. Beberapa penelitian telah membahas bagaimana mengembangkan metode penentuan parameter PID pada motor $\mathrm{dc}$, salah satu metode tersebut adalah berbasis metode kecerdasan buatan, diantaranya Artificial Bee Colony [3], Particle Swarm 
Optimization [4,8], Evolutionary Algorithm [7,11], Bio-Inspired Algorithm [9], Tabu Search [12], Bacterial Foraging [10], Fuzzy Logic [13,14], Cuckoo Search [15], dan Flower Algorithm [16]. Dari beberapa penelitian yang telah dilakukan menunjukkan pengembangan metode penalaan parameter PID dengan menggunakan metode kecerdasan buatan.

Salah satu metode cerdas yang akan dibahas pada penelitian ini adalah metode firefly. Metode firefly dipublikasikan Pada tahun 2009, oleh seorang peneliti Xin Xhe Yang, yang menemukan sebuah metode cerdas yang disebut kecerdasan firefly dan membuat sebuah algoritma penyelesaian yang terinspirasi dari perilaku firefly dalam berkedip. Untuk itu, pada penelitian ini akan digunakan salah satu metode cerdas (Artificial Intelligent) untuk menala parameter PID motor DC yaitu dengan metode Firefly Algorithm (FA) dan akan dianalisa dan dibandingkan respon kecepatan motor DC dengan metode konvensional PID trial-error serta motor DC tanpa kontroler.

\section{PEMODELAN SISTEM}

Motor DC adalah motor listrik yang memerlukan suplai tegangan arus searah (DC) pada kumparan medan untuk diubah menjadi energi gerak mekanik. Kumparan medan pada motor dc disebut stator (bagian yang tidak berputar) dan kumparan jangkar disebut rotor (bagian yang berputar). Motor arus searah, sebagaimana namanya, menggunakan arus langsung yang tidak langsung/directunidirectional. Motor DC memiliki 3 bagian utama untuk dapat berputar yaitu : Kutub Medan, Dinamo dan Komutator $[15,16]$.

Untuk merancang dan mensimulasikan suatu sistim kontrol kecepatan motor DC diperlukan adanya model matematika dari plant yang akan dikontrol. Sehingga dalam memudahkan analisis sistem bisa digambarkan ke dalam model statis, model fisis (rangkaian listrik) dan dinamik (diagram blok dan transfer function).

\subsection{Pemodelan Motor DC $[15,16]$}

Pemodelan motor DC yang digunakan mengacu pada sebuah paper yang di mana menggunakan pemodelan transfer function. Motor DC yang digunakan di sini adalah menggunakan motor DC magnet permanen, rating kecepatan 1400 rpm dengan kecepatan saat pengukuran $1250 \mathrm{rpm}$. Dengan memasukkan kecepatan motor DC, maka transfer function motor DC adalah,

$$
G(s)=\frac{K_{m}}{T_{m} s+1}
$$

Di mana, Km adalah gain mekanik dan Tm adalah waktu konstan mekanik.

$$
G(s)=\frac{2.75}{0.18 s+1}
$$

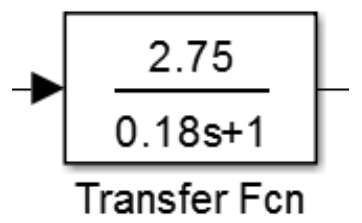

Gambar 1. Pemodelan Motor DC di Simulink

\subsection{Pemodelan Kontroler PID $[15,16]$}

Berikut persamaan pemodelan kontroler PID yang digunakan pada penelitian ini, berdasarkan $[15,16]$.

$$
u(t)=k_{p}\left[e(t)+\frac{1}{T_{i}} \int_{0}^{t} e(t) d t+T_{d} \frac{d e_{t}}{d t}\right]
$$

Di mana, $u(t)$ adalah nilai kontrol yang dihitung oleh kontroler PID, Kp adalah koefisien proporsional, Ti adalah integral waktu konstan dan $\mathrm{Td}$ adalah konstanta waktu differensial. Fungsi dari ketiga elemen tersebut adalah :

1. Proporsional: menggambarkan sinyal deviasi e $(\mathrm{t})$ dari sistem kontrol proporsional. ketika sinyal e(t) ada, kontroler PID menghasilkan efek kontrol segera untuk mengurangi penyimpangan.

2. Integral : digunakan untuk menghilangkan kesalahan statis dan meningkatkan stabilitas sistem.

3. Diferensial : mencerminkan perubahan penyimpangan sinyal, memperkenalkan sinyal koreksi sebelum penyimpangan nilai sinyal menjadi lebih besar dan mempercepat respon sistem untuk mengurangi pengaturan waktu.

Oleh karena itu, merancang kontroler PID terutama berarti menentukan tiga parameter, serta bagaimana mengkonfigurasi ke tiga 
parameter PID (Kp, Ki, Kd). Dalam penelitian ini, Firefly Algorithm diusulkan untuk mencari parameter optimal PID. Blok diagram sistem kontrol keseluruhan dan blok PID ditunjukkan pada Gambar 2 dan 3

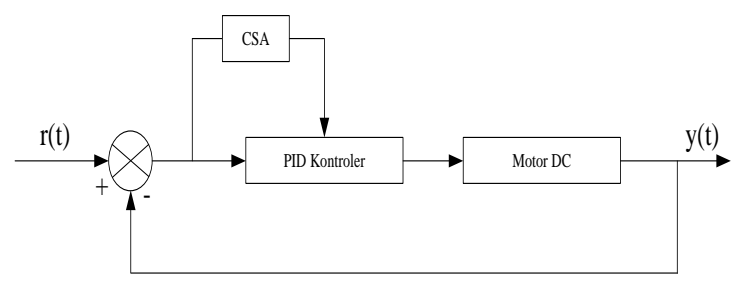

Gambar 2. Sistem Kontroler PID-Firefly

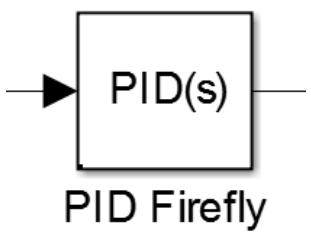

Gambar 3. Pemodelan PID di Simulink

\section{FIREFLY ALGORITHM [1]}

Algoritma ini pertama ditemukan oleh Dr. Xin-She Yang di Universitas Cambridge pada tahun 2007. Pada algoritma ini terdapat tiga perumusan dasar :

1. Semua firefly adalah unisex, jadi suatu firefly akan tertarik dengan firefly lain terlepas dari jenis kelamin mereka.

2. Daya tarik sebanding dengan kecerahan, maka firefly dengan kecerahan lebih redup akan bergerak ke arah firefly dengan kecerahan lebih terang dan kecerahan berkurang seiring dengan bertambah jarak. Apabila tidak ada firefly yang memiliki kecerahan paling cerah maka firefly akan bergerak random.

3. Tingkat kecerahan firefly dideterminasikan oleh tempat dari fungsi objektif firefly.

Dalam proses permasalahan optimisasi, kecerahan cahaya firefly adalah sebanding untuk nilai dari fungsi tujuan. Bentuk lain dari kecerahan dapat didefinisikan pada cara yang sama untuk fungsi fitness pada algoritma genetika. Berdasarkan pada ketiga peraturan ini, langkah dasar dari algoritma firefly (FA) dapat diringkas sebagai pseudo code pada Tabel 1 :
Tabel 1. Pseudo Code Firefly

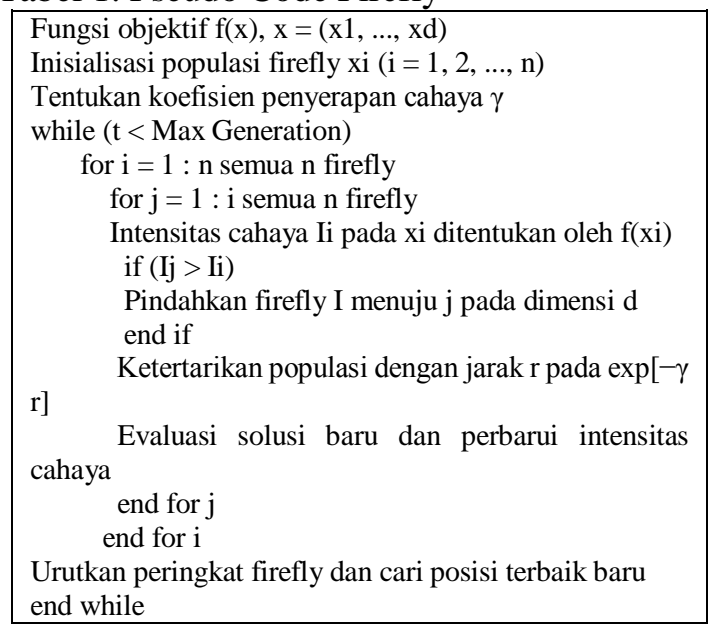

\subsection{Penalaan PID dengan Firefly}

Gambar 4 menunjukkan diagram alir algoritma metode Firefly Algorithm (FA) yang digunakan pada penelitian ini untuk menala parameter PID. Fungsi objektif yang digunakan untuk menguji kestabilan sistem adalah dengan Integral Time Absolut Error (ITAE).

$$
\text { ITAE }=\int_{0}^{t} t|\Delta \omega(t)| d t
$$

Parameter PID yang ditala oleh FA adalah $\mathrm{Kp}$, Ki dan Kd. Adapun untuk diagram alir proses penalaan parameter PID dengan menggunakan metode Firefly Algorithm (CSA) ditunjukkan oleh flowchart pada Gambar 4. Gambar 5 menunjukkan pemodelan motor DC pada Simulink Matlab 2015, tanpa kontrol, dengan Bee Colony, Cuckoo Search dan PID Firefly.

Untuk menjalankan algoritma firefly dibutuhkan beberapa parameter, yang disebutkan pada Tabel 2. Algoritma firefly dibuat menggunakan software Matlab (m.files) dan pemodelan motor menggunakan Simulink Matlab. Adapun data parameter-parameter firefly adalah berikut,

Tabel 2. Parameter Firefly

\begin{tabular}{|c|c|}
\hline Parameter & Nilai \\
\hline Alpha & 0.25 \\
\hline Beta & 0.2 \\
\hline Gamma & 1 \\
\hline Dimensi & 80 \\
\hline Jumlah Firefly & 80 \\
\hline Iterasi Maksimum & 50 \\
\hline
\end{tabular}


Setelah memasukkan beberapa parameter tersebut di Tabel 2, maka selanjutnya algoritma Firefly bisa dijalankan untuk optimasi nilai PID dari controller. Nilai yang tepat akan sangat mempengaruhi kinerja respon motor DC yang didesain pada penelitian ini. Algoritma Firefly membutuhkan proses perhitungan sampai menemukan nilai yang optimal. Gambar 6 menunjukkan grafik konvergensi optimasi nilai PID menggunakan algoritma firefly. Konvergensi adalah suatu nilai fitness function yang menjabarkan kriteria optimal dari suatu masalah optimasi.

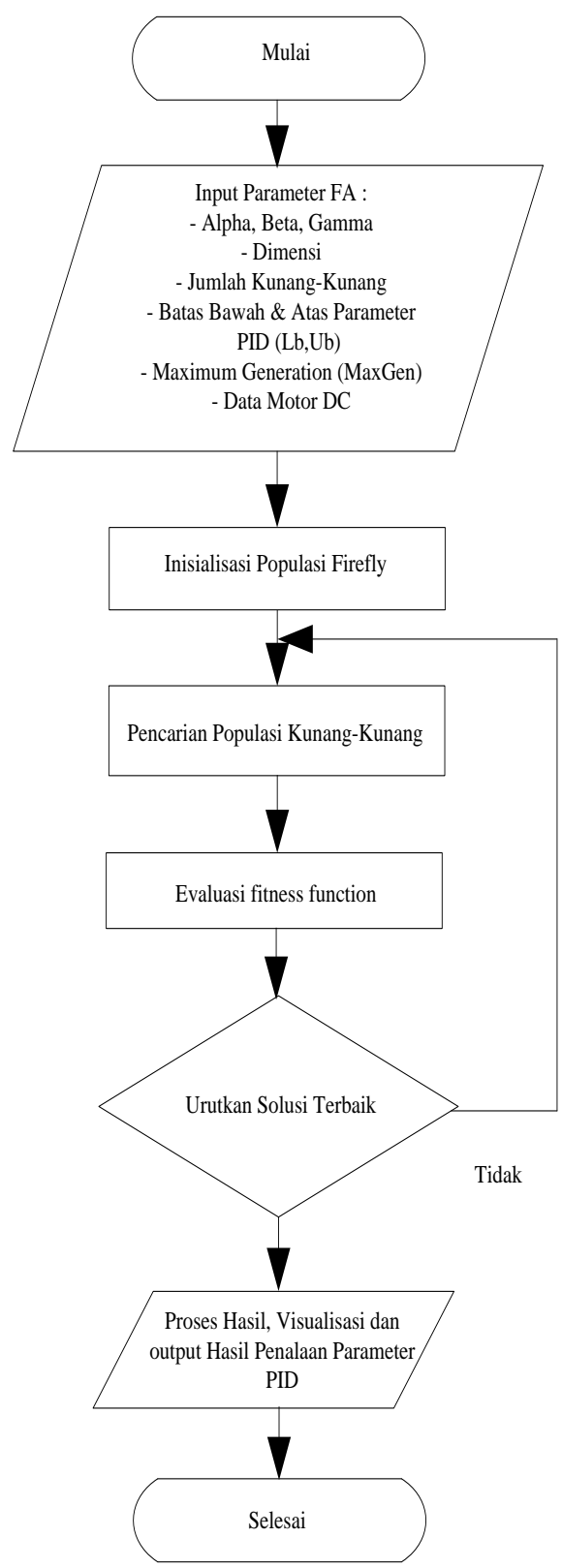

Gambar 4. Flowchart Penelitian
Gambar 6 menunjukkan grafik konvergensi optimasi nilai PID menggunakan firefly, di mana berdasarkan grafik terlihat algoritma firefly tidak membutuhkan waktu yang lama dalam melakukan proses optimasi, hal tersebut terlihat pada iterasi ke 7 algoritma sudah menemukan nilai PID yang optimal dengan nilai fitness sebesar 6.2269. Untuk hasil selengkapnya dapat dilihat pada Tabel 3.

Tabel 3. Hasil Optimasi dengan Firefly

Total number of iterations $=50$
fmin $=6.2269$
nbest $=400003.1641 \quad 1.0000$
kp_ff $=40$
ki_ff $=3.1641$
kd_ff $=1$

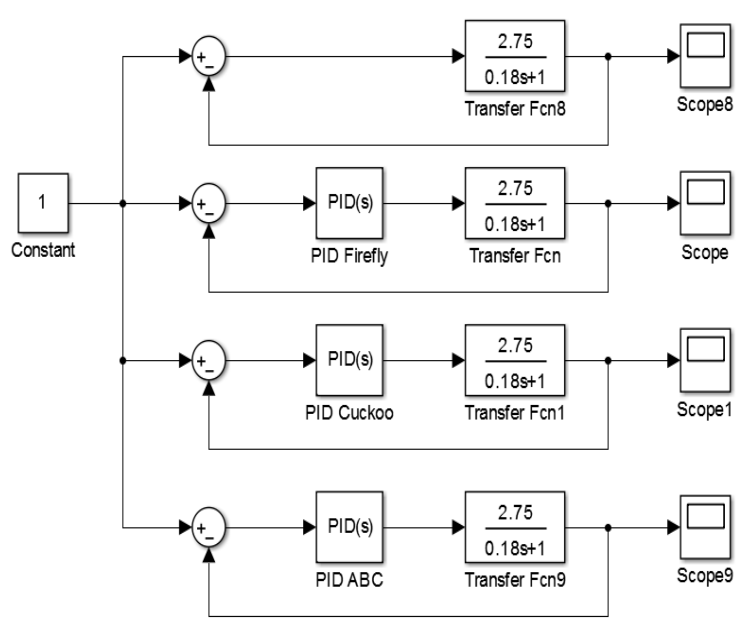

Gambar 5. Pemodelan Motor DC di Simulink

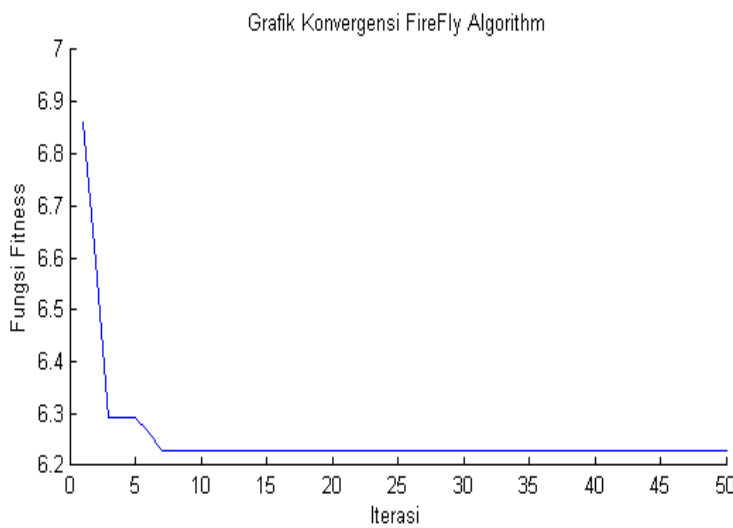

Gambar 6. Grafik Konvergensi Optimasi Kontrol PID Motor DC dengan Firefly Algorithm

Hasil optimasi Firefly didapatkan nilai fitness function sebesar 6.2269, dengan 50 kali 
iterasi, nilai nbest merupakan firefly terbaik, yang di mana diketahui sebagai hasil optimasi parameter PID, yaitu Kp, Ki dan Kd. Tabel 3 menunjukkan nilai hasil optimasi parameter PID ditala oleh Firefly. Sebagai pembanding digunakan algoritma Bee Colony. Bee Colony merupakan salah satu algoritma cerdas yang dalam hal ini digunakan dari penelitian sebelumnya. Bee Colony merupakan algoritma yang bekerja berdasarkan perilaku lebah dalam mencari sumber makanan. Sumber makanan di sini diasumsikan sebagai nilai PID yang akan dioptimasi.

Tabel 5. Hasil Penalaan Parameter PID

\begin{tabular}{|c|c|c|c|}
\hline Param. & $\begin{array}{c}\text { Bee } \\
\text { Algorithm }\end{array}$ & $\begin{array}{c}\text { Cuckoo } \\
\text { Algorithm }\end{array}$ & $\begin{array}{c}\text { Firefly } \\
\text { Algorithm }\end{array}$ \\
\hline $\mathrm{Kp}$ & 0.2960 & 4.36 & 40 \\
\hline $\mathrm{Ki}$ & 0.0923 & 9.1 & 3.1641 \\
\hline $\mathrm{Kd}$ & 0.0491 & 0.59 & 1 \\
\hline
\end{tabular}

\section{HASIL SIMULASI DAN ANALISIS}

\subsection{Respon Kecepatan Motor DC tanpa Controller}

Simulasi pertama adalah simulasi open loop Motor DC tanpa controller. Berikut hasil simulasi.

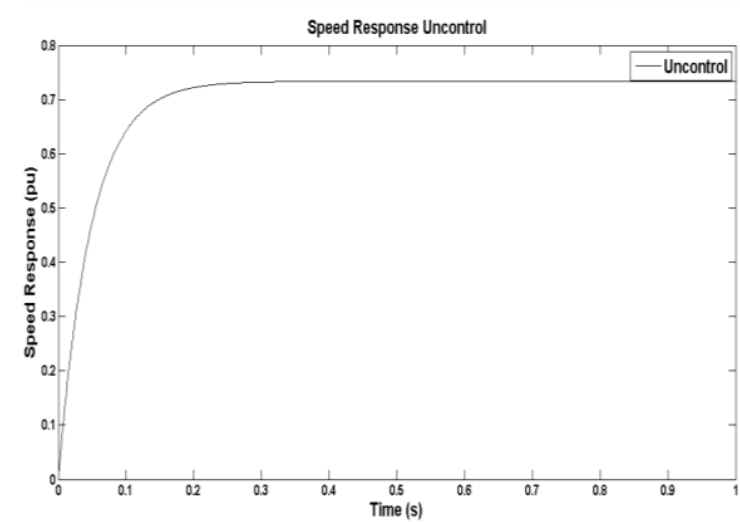

Gambar 7. Respon Kecepatan Motor DC tanpa kontrol, untuk $\mathrm{t}=1 \mathrm{~s}$.

Gambar 7 menunjukkan hasil simulasi tanpa kontroler, didapatkan respon kecepatan motor DC yang sangat tinggi, hal ini dikarenakan sistem tidak ada umpan balik, sehingga motor bekerja tanpa ada batasan dan untuk sistem yang seperti ini sangat dihindari. Untuk itu sangat diperlukan desain sistem kontrol yang tepat dengan penambahan kotroler PID pada motor DC, sehingga kecepatan yang dihasilkan dapat dikontrol sesuai dengan beban yang dikopel oleh motor DC.

\subsection{Respon Kecepatan Motor DC dengan PID Bee Colony}

Simulasi yang kedua adalah kontrol motor DC dengan PID Bee Colony, berikut hasil simulasinya pada Gambar 8 dan 9.

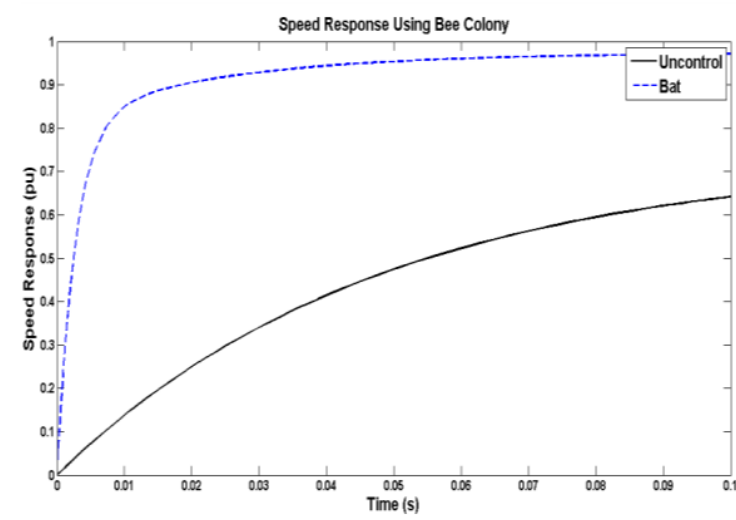

Gambar 8. Respon Kecepatan Motor DC dengan PID Bee Colony, $\mathrm{t}=0.1 \mathrm{~s}$

Untuk lebih jelasnya berikut untuk $\mathrm{t}=1 \mathrm{~s}$.

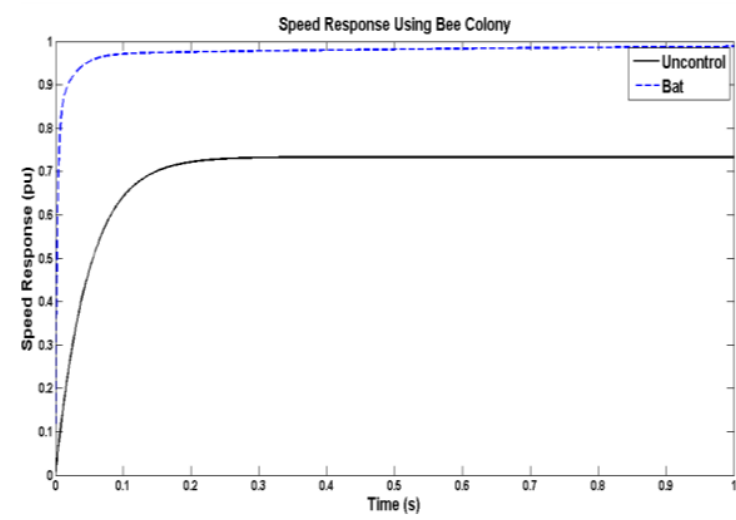

Gambar 9. Respon Kecepatan Motor DC dengan PID Bee Colony, $\mathrm{t}=1 \mathrm{~s}$

Gambar 8 dan 9 menunjukkan grafik respon frekuensi motor DC dengan PID Bee Colony. Dari grafik di atas didapatkan settling time yang semakin baik dibanding dengan tanpa control, namun kinerja PID pada system ini masih bisa dioptimalkan dengan penalaan yang tepat. Dari grafik dapat dilihat, respon system sudah sangat baik dalam mencapai kondisi steady state sebelum $\mathrm{t}=1 \mathrm{~s}$. 


\subsection{Respon Kecepatan Motor DC dengan PID Cuckoo Search Algorithm}

Simulasi yang ketiga adalah kontrol motor DC dengan menggunakan PID Cuckoo, berikut hasil simulasinya.

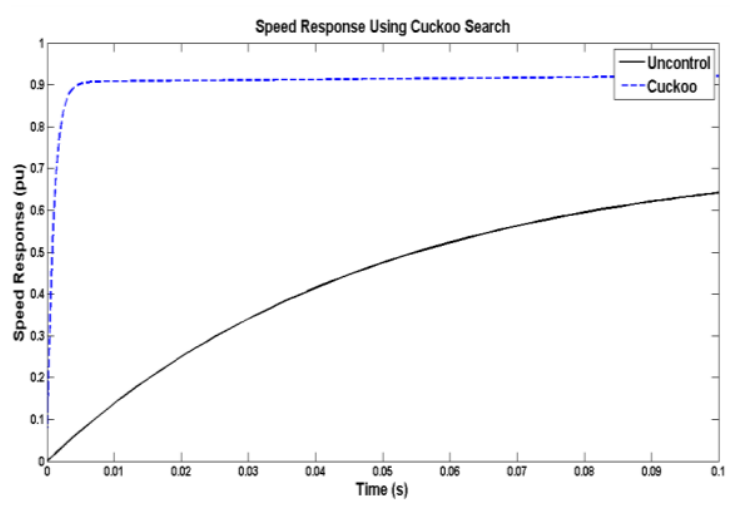

Gambar 10. Respon Kecepatan Motor DC dengan PID Cuckoo, $\mathrm{t}=0.1 \mathrm{~s}$

Untuk lebih jelasnya berikut untuk $\mathrm{t}=1 \mathrm{~s}$.

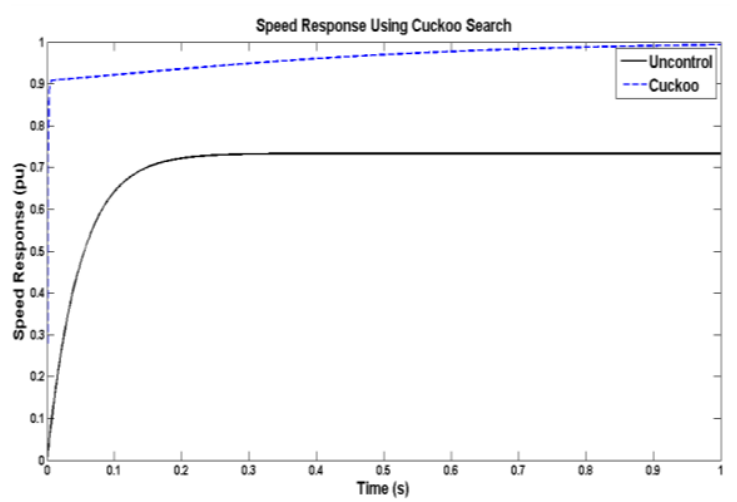

Gambar 11. Respon Kecepatan Motor DC dengan PID Cuckoo t=1s

Gambar 10 dan 11 menunjukkan grafik respon frekuensi motor DC dengan PID Cuckoo. Dari grafik di atas didapatkan settling time yang sangat cepat dibanding dengan metode bee colony, di mana sistem sudah berada pada kondisi steady sebelum $\mathrm{t}=1 \mathrm{~s}$. Kinerja PID pada system ini masih bisa untuk dioptimalkan.

\subsection{Respon Kecepatan Motor DC dengan PID Firefly}

Simulasi yang keempat menggunakan metode yang diusulkan pada penelitian ini, yaitu menggunakan metode firefly. Berikut hasil simulasi percobaan motor de pada Gambar 12 dan 13.

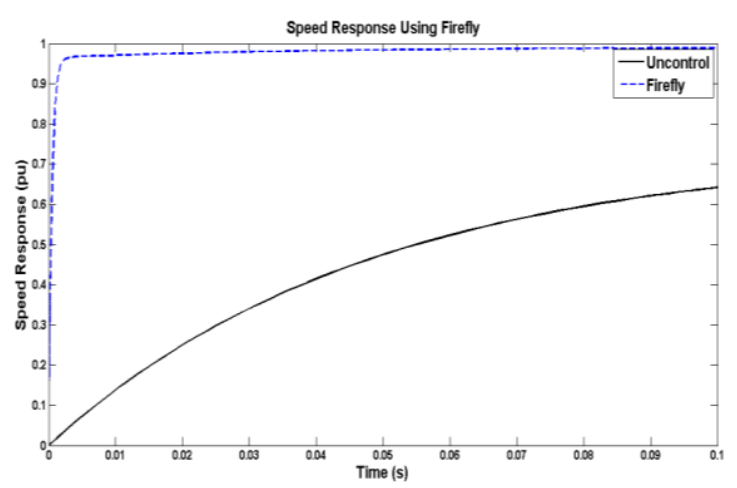

Gambar 12. Respon Kecepatan Motor DC dengan PID Firefly, $t=0.1 \mathrm{~s}$

Untuk lebih jelasnya berikut untuk $\mathrm{t}=1 \mathrm{~s}$.

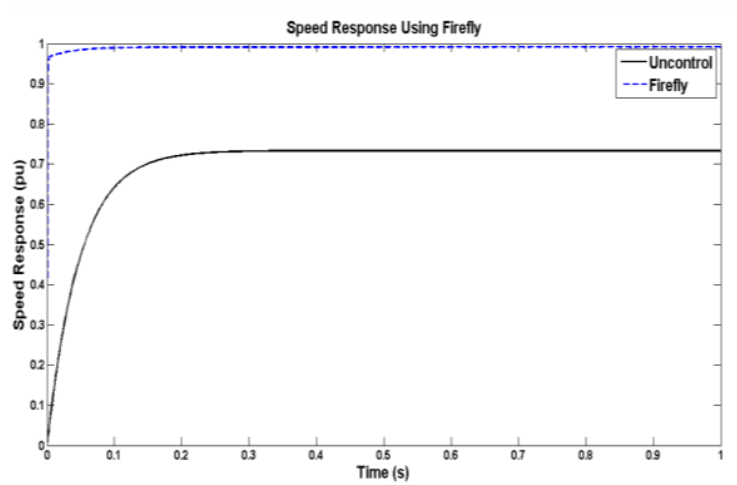

Gambar 13. Respon Kecepatan Motor DC dengan PID Firefly, $t=1 \mathrm{~s}$

Gambar 12 dan 13 menunjukkan grafik respon frekuensi motor DC dengan PID Firefly. Dari grafik 12 dan 13 didapatkan settling time yang sangat cepat dengan menggunakan firefly, dibanding dengan metode bee colony dan cuckoo, di mana sistem lebih cepat berada pada kondisi steady. Hal tersebut dikarenakan parameter PID sudah optimal pada system ini sehingga respon motor yang didapat semakin baik dalam merespon dinamika motor dc saat starting awal.

Dapat disimpulkan bahwa dengan menggunakan metode cerdas untuk mengoptimasi parameter PID, hasil yang didapat untuk kinerja PID sangat baik karena menunjukkan respon yang cepat untuk kontrol motor DC. Gambar 14 menunjukkan perbandingan dari kontrol motor DC tanpa 
control, dengan metode cuckoo, bee colony dan firefly yang telah disimulasikan.

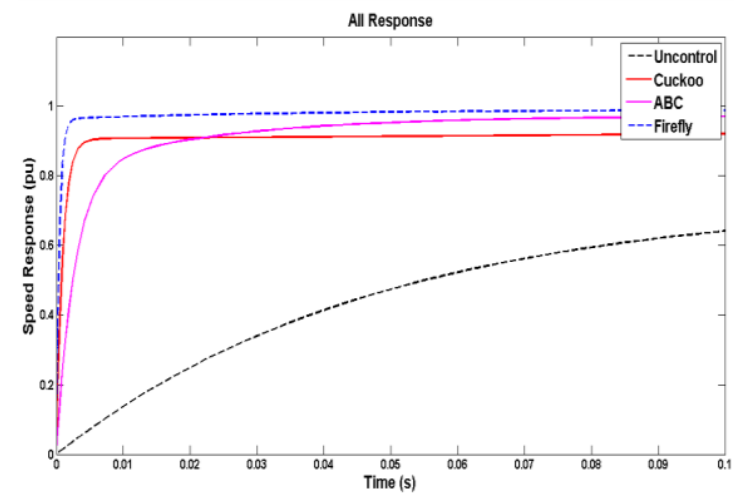

Gambar 14. Perbandingan Respon Kecepatan Motor DC, $\mathrm{t}=0.1 \mathrm{~s}$

Untuk lebih jelasnya Gambar 15 memperlihatkan respon untuk $\mathrm{t}=1 \mathrm{~s}$.

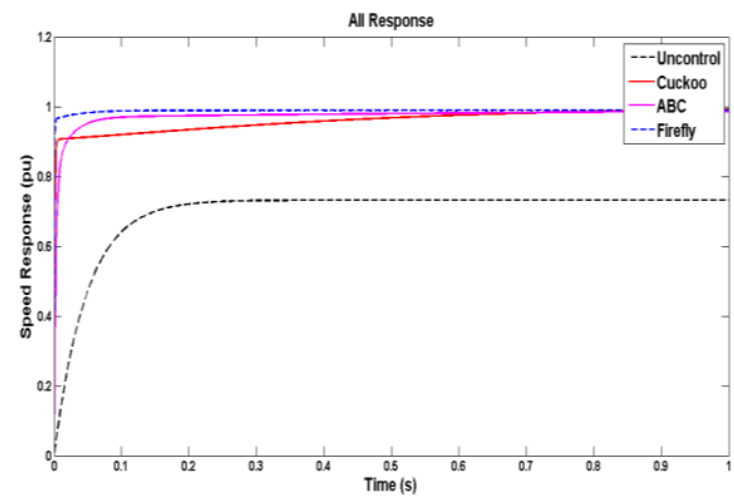

Gambar 15. Perbandingan Respon Kecepatan Motor DC, $\mathrm{t}=1 \mathrm{~s}$

Aplikasi motor DC sangat banyak digunakan, karena motor DC sangat cocok untuk aplikasi terutama pengontrolan, sehingga dibutuhkan desain kontroler motor DC yang tepat, dalam hal ini sangat diusulkan untuk menggunakan kontroler PID karena sangat simple untuk pengontrolan sistem dengan penalaan parameter menggunakan metode cerdas yang tepat akan didapatkan kinerja yang baik.

\section{KESIMPULAN}

Dengan menggunakan metode cerdas Firefly Algorithm sebagai metode penalaan PID
Controller, didapatkan hasil penalaan parameter nilai $P I D$ yang optimal di mana, $K p$ sebesar 40, $K i$ sebesar 3.1641 dan $K d$ sebesar 1.

Dari hasil simulasi dapat disimpulkan, respon kecepatan motor DC dengan PID Firefly, didapatkan settling time yang sangat cepat dibanding dengan metode Bee Colony dan Cuckoo Search, di mana sistem sudah berada pada kondisi steady sebelum $\mathrm{t}=1 \mathrm{~s}$.

Metode Firefly dapat digunakan untuk mengoptimasi parameter PID, hasil yang didapat untuk kinerja PID sangat baik karena menunjukkan respon yang cepat untuk kontrol motor DC.

\section{DAFTAR PUSTAKA}

[1] Yang, X,S. "Cuckoo Search and Firefly Algorithms Theory and Applications". 2013.

[2] Yang, X,S, "Nature-Inspired Metaheuristic Algorithms", Frome: Luniver Press. 2008.

[3] Wudai Liao, "Optimization of PID Control for DC Motor Based On Artificial Bee Colony Algorithm". IEEE, 2014.

[4] X. Wang, and M. Zhang, "Optimizing PID parameters by using improved particle swarm optimization algorithm", Process Automation Instrumentation, no. 2, pp. 1-9, 2004.

[5] B. Liu, J. Tan, and C. Huang, "Research and Application of an Improved PID Control Algorithm", Microcomputer Information, vol. 6, no. 1, pp. 15-17, 2007.

[6] D. Chen, K. Fang, and Q. Chen, "Application of genetic algorithm in PID parameters optimization", Microcomputer Information, vol. 23, no.3, pp. 35-36, 2007.

[7] H. He and F. Qian, "The PID parameter tuning based on immune evolutionary algorithm", Microcomputer Information, vol. 27, no. 5, pp. 1174-1176, 2007.

[8] W. Zhang, "Increment PID controller based on immunity particle swarm 
optimization algorithm", Microcomputer Information, vol. 28, no.7, pp. 67-69, 2010.

[9] Nitish Katal. "Optimal Tuning of PID Controller for DC Motor using BioInspired Algorithms", International Journal of Computer Applications.2012.

[10] Bharat Bhushan, "Adaptive control of DC motor using bacterial foraging algorithm", Applied Soft Computing sciencedirect. 2011.

[11] Ashu Ahuja, "Design of fractional order PID controller for DC motor using evolutionary optimization techniques".WSEAS Transactions on Systems and Control, 2014.

[12] Anant Oonsivilai, "Optimum PID Controller tuning for AVR System using Adaptive Tabu Search", 12th WSEAS International Conference on COMPUTERS, Heraklion, Greece, July 23-25, 2008.

[13] Umesh Kumar Bansal, "Speed Control of DC Motor Using Fuzzy PID Controller", Advance in Electronic and Electric Engineering. 2013.

[14] K. Premkumar, "Fuzzy PID supervised online ANFIS based speed controller for brushless dc motor". Sciencedirect. Neuro Computing, 2015.

[15] Djalal.M.R, D. Ajiatmo, A. Imran, I. Robandi, "Desain Optimal Kontroler PID Motor DC Menggunakan Cuckoo Search Algorithm", Seminar Nasional Teknologi Informasi dan Aplikasinya (SENTIA) Politeknik Negeri Malang, 2015.
[16] D. Lastomo, Djalal. M. R, Widodo, I.Robandi, "Optimization of PID Controller Design for DC Motor Based on Flower Pollination Algorithm", The 2015 International Conference on Electrical, Telecommunication and Computer Engineering (ELTICOM 2015), 2015.

\section{Biodata Penulis}

Muhammad Ruswandi Djalal, Lahir di Ujung Pandang 11 Maret 1990. Menyelesaikan D4 bidang keahlian Teknik Pembangkit Energi di Politeknik Negeri Ujung Pandang pada tahun 2012. S2 di Institut Teknologi Sepuluh Nopember bidang keahlian Teknik Sistem Tenaga. Sekarang Dosen di Teknik Energi Politeknik Negeri Ujung Pandang.

Hidayatul Nurohmah, Lahir di Jobang 1969. S1 bidang keahlian Sistem Tenaga di Universitas Darul Ulum Jombang, S2 bidang keahlian Sistem Tenaga di Institut Teknologi Sepuluh Nopember. Sekarang Dosen di Teknik Elektro Universitas Darul Ulum Jombang.

Andi Imran, Lahir di Bantaeng tahun 1985. S1 teknik elektro di Universitas Negeri Makassar, S2 bidang keahlian teknik energi di Universitas Hasanuddin. Sekarang sedang menyelesaikan S3 bidang keahlian teknik system tenaga di Institut Teknologi Sepuluh Nopember Surabaya.

Muhammad Yusuf Yunus, Lahir di Sinjai 20 Agustus 1980. D4 teknik energi politeknik elektronika negeri Surabaya. S2 teknik energy di Universitas Hasanuddin. Sekarang Dosen di Teknik Energi Politeknik Negeri Ujung Pandang. 